\title{
KEMAJUAN DESA DAN PRODUK UNGGULAN PERTANIAN DI KABUPATEN BOMBANA SULAWESI TENGGARA
}

\author{
Azhar Amir ${ }^{\left.1^{*}\right)}$ \\ ${ }^{1}$ Pusat Penelitian Pengembangan, Balilatfo. Kementerian Desa \\ Pembangunan Daerah Tertinggal dan Transmigrasi \\ *Corresponding author : accabonsky13@gmail.com
}

To cite this article:

Amir, A. (2020). Kemajuan Desa dan Produk Unggulan Pertanian di Kabupaten Bombana Sulawesi Tenggara. Jurnal Ilmiah Membangun Desa dan Pertanian, 5(2), 45 - 51. doi:http://dx.doi.org/10.37149/jimdp.v5i2.10880

Received: February 04, 2020; Accepted: February 28, 2020; Published: March 04, 2020

\begin{abstract}
The aims of this study were to identify the status of village progress based on the value of the village development index (IDM) and to identify the leading commodity in the agricultural sector in Bombana Regency. The main data of this study are secondary data of villages IDM, which were sourced from The Ministry of Villages, Disadvantaged Areas Development and Transmigration, agricultural production in Bombana Regency and Southeast Sulawesi Province, which were sourced from the Central Statistics Board of Indonesia. The Data were analyzed using descriptive and quantitative analysis methods, namely composite index analysis of IDM and location Quotient (LQ) analysis The data showed a village that has progressed to become a developed village namely Waemputtang Village with an index value of 0.7335 . The leading food crop products are rice plants. there are 18 districts in Bombana Regency which produce rice. the types of livestock that are surplus and progressive in Bombana are cows, buffaloes, native chickens. These leading commodities already have a value of $L Q>1$
\end{abstract}

Keywords: developed village; leading sector; location quotient; village index

\section{PENDAHULUAN}

Undang Undang Desa merupakan pendukung utama untuk mempercepat capaian program pembangunan desa. masyarakat desa diberikan kewenangan dan menjadi pelaku utama pada pelaksanaan program desa yang telah ditetapkan bersama. Program ini diharapkan meningkatkan sumber daya manusia (SDM), pengembangan usaha ekonomi desa, meningkatkan kesejahteraan masyarakat, mengatasi kemiskinan, perbaikan infrastruktur desa, pemanfaatan sumber daya alam (SDA) dan lingkungan secara berkelanjutan. Salah satu upaya pemenuhan didukung dengan adanya dana desa yang telah disalurkan sejak tahun 2015 sampai 2019 sebesar Rp. 257 triliun (Affandi, 2019). Pemerintah memberikan perhatian yang besar untuk kemajuan desa-desa di Indonesia. Jumlah dana desa yang disalurkan pada tahun 2020 meningkat 2 triliun dari tahun sebelumnya menjadi 72 triliun rupiah untuk 74.953 desa di Indonesia (Pemerintah RI, 2019).

Penetapan prioritas penggunaan dana desa dapat mempertimbangkan tipologi Desa berdasarkan tingkat perkembangan desa. Perkembangan desa secara berurut meliputi desa sangat tertinggal, desa tertinggal, desa berkembang, desa maju dan desa mandiri. Hal tersebut sesuai dengan status Indeks Desa Membangun (IDM). IDM berfungsi sebagai pemetaan pengembangan desa melalui pengukuran indikator ketahanan sosial (IKS) seperti kesehatan, pendidikan modal sosisl dan pemukiman, indikator ketahanan ekonomi (IKE) seperti kergaman produksi masyarakat desa, akses distribusi/logistik, lembaga ekonomi dan keterbukaan wilayah dan indikator ketahanan lingkungan (IKL) berupa kualitas lingkungan dan potensi/rawan bencana alam (Kementerian Desa PDTT, 2016). IDM merupakan indeks komposit yang dapat menjadi acuan pengentasan desa tertinggal dan atau kemajuan desa melalui partisipasi dan prakarsa masyarakat desa sebagai subyek pembangunan desa. 
Lima tahun yang lalu, pemerintah menetapkan daerah tertinggal sebanyak 122 kabupaten. Kondisi saat ini menurun menjadi 60 kabupaten tertinggal. Sehingga terdapat 62 kabupaten yang terentaskan dari ketertinggalan dan Kabupaten Bombana merupakan salah satu dari daftar tersebut (Kementerian Desa PDTT, 2019). Sinergi pemerintah daerah dengan pemerintah pusat serta aparatur desa juga baik untuk keluar dari daerah tertinggal. Hal ini terlihat dari adopsi inovasi desa dan program gembira desa yang meningkatkan partisipasi dan pemberdayaan masyarakat desa. Implikasinya adalah terjadi peningkatan indikator dari IDM di sebagian besar desa di Kabupaten Bombana sebesar $7,12 \%$.

Potensi wilayah Kabupaten Bombana adalah sektor pertanian. Terdapat 18 dari 22 kecamatan menghasilkan tanaman pangan. Sektor ini bersama dengan sub sektor kehutanan dan perikanan menyerap tenaga kerja $43,15 \%$ dan kontribusi ke Produk Domestik Regional Bruto (PDRB) yang lebih baik dari sektor lainnya 29,67\% (BPS Kabupaten Bombana, 2019). Abidin (2015) bahwa Kabupaten Bombana secara terspesialisasi memiliki keunggulan komparatif pada subsektor tanaman pangan dan peternakan di tahun 2000-2013. Abidin (2018) menambahkan bahwa komoditas basis di Kabupaten Bombana pada tahun 2016 antara lain tanaman padi, ternak sapi, jambu mete dan jahe. Optimalisasi komoditas unggulan ini merupakan salah satu cara pengembangan ekonomi di suatu wilayah dan memiliki nilai tambah bagi pengetahuan dan pendapatan bagi masyarakat (Jufriyanto, 2019). Program kebijakan di suatu daerah sebaiknya memperhatikan potensi SDA dan SDM. (Yunisa et al., 2019) bahwa penetapan program desa gembira seperti pengadaan atau perbaikan irigasi, pemberian bibit unggul, bantuan alat mekanisasi pertanian serta pelayanan masyarakat sesuai kebutuhan berdasarkan hasil musyawarah desa.

Kajian tentang IDM di suatu wilayah telah dilakukan lima tahun terakhir. Lihat misalnya Setyobakti (2017) tentang IDM di Kabupaten Malang, Jumiadin \& Asuhadi (2018) tentang IDM, IPD dan IKL di Kabupaten Wakatobi, Muhtarom, et al. (2018) tentang IDM di Pringsewu, Setyowati (2019) tentang IDM di Kabupaten Malang, Suroso (2019) tentang IPD dan IDM di Kabupaten Pati. Penelitian-penelitian tersebut mengindikasikan indikator ketahanan sosial, ekonomi dan lingkungan merupakan kekuatan dalam meningkatkan partisipasi masyarakat sebagai pelaku dalam pembangunan desanya. Undang Undang Desa mempunyai arah tujuan tersebut sehingga pembangunan desa, peningkatan usaha ekonomi dilakukan oleh tumbuhnya prakarsa masyarakat. Pembahasan IDM di Kabupaten Bombana masih terbatas informasinya. Padahal ini penting untuk mengetahui tahapan perkembangan desa sehingga kebijakan yang diambil dapat tepat sasaran sesuai kekuatan dan kelemahan pada indikator yang telah diketahui. Potensi produk sektor pertanian juga perlu dikaji ulang pada kondisi saat ini yang telah berubah kondisi dan luas lahan usaha masyarakat desa. Berdasarkan hal tersebut maka tujuan dari kajian ini adalah mengetahui status kemajuan desa berdasarkan nilai IDM dan mengetahui komoditas unggulan komparatif subsektor pertanian di Kabupaten Bombana.

\section{MATERI DAN METODE}

Kabupaten Bombana, Sulawesi Tenggara merupakan subjek penelitian ini dan objek yang diteliti adalah data kuantitatif nilai IDM berupa IKS, IKE dan IKL desa dan subsektor pertanian meliputi tanaman pangan serta jenis ternak. Jenis data yang digunakan adalah data sekunder yang diperoleh dari BPS Kabupaten Bombana, BPS Provinsi Sulawesi Tenggara dan Kemendesa PDTT dengan data IDM 2015-2019. Beberapa data dan informasi juga dikumpulkan berupa kajian pustaka dan instansional.

Analisis yang digunakan untuk menjawab tujuan pertama tentang status kemajuan desa diukur sesuai data IDM desa (Kementerian Desa PDTT, 2016). IDM merupakan indeks komposit dari dimensi sosial, ekonomi dan lingkungan. Dimensi dan variabel IDM dapat dilihat pada Tabel 1.

Tabel 1. Indikator dan variabel IDM

\begin{tabular}{lll}
\hline Dimensi & \multicolumn{1}{c}{ Variabel } \\
\hline \multirow{3}{*}{$\begin{array}{c}\text { Ketahanan } \\
\text { Sosial }\end{array}$} & $\begin{array}{l}\text { Jasa Kesehatan, Akses dan Aktivitas Masyarakat ke } \\
\text { Layanan Kesehatan, Tingkat kepesertaan BPJS }\end{array}$ \\
\cline { 2 - 3 } & Pendidikan & $\begin{array}{l}\text { Jarak ke Lembaga Pendidikan Formal, Jarak ke Lembaga } \\
\text { Pelatihan/ Kursus, Taman Baca atau Perpustakaan }\end{array}$ \\
\cline { 2 - 4 } & $\begin{array}{l}\text { Keberadaan Kelompok Mayarakat, Kerukunan Suku dan } \\
\text { Umat Beragama, Keamanan dan Ketertiban Lingkungan } \\
\text { Desa, Kesejahteraan Sosial }\end{array}$ \\
\hline Permukiman & $\begin{array}{l}\text { Ketersediaan Sumber Air Bersih, Fasilitas Saranan dan } \\
\text { Prasarana Mandi Cuci Kakusi (MCK), Sarana Listrik, Media }\end{array}$ \\
\hline
\end{tabular}


Tabel 1. Indikator dan variabel IDM

\begin{tabular}{ll}
\hline Dimensi & \multicolumn{1}{c}{ Komunikasi } \\
\hline Ketahanan & Variasi Kegiatan Ekonomi Masyarakat, Keberadaan Pusat Perniagaan, Jasa \\
Ekonomi & Logistik, Bantuan Usaha dari Perbankan, Ketersediaan Koperasi dan atau \\
& Badan Usaha Milik Desa, Kondisi Jalan dan Sarana Transportasi \\
\hline Ketahanan Ekologi & Tingkat Pencemaran Lingkungan, Kerentanan Bencana Alam \\
\hline
\end{tabular}

Sumber : Kemendesa PDTT, 2016, diolah

Nilai IDM merupakan gabungan dari ketiga dimensi tersebut. Ketiga dimensi ini terdiri dari variable dan setiap varibael memiliki indikator operasional. Nilai IDM dinyatakan dalam rumus sebagai berikut (Kementerian Desa PDTT, 2016) :

Keterangan :

$$
I D M=\frac{1}{3}(I K S+I K E+I K L)
$$

IDM : Indeks Desa Membangun

IKS : Indeks Ketahanan Sosial

IKE : Indeks Ketahanan Ekonomi

IKL : Indeks Ketahanan Lingkungan

Penentuan komoditas unggulan dianalisis dengan Location Quotient analysis. Rumus Location Quotient merupakan rasio peluang satu komoditas terhadap jumlah himpunan komoditas wilayah dengan peluang nilai satu variabel komoditas terhadap populasi. Persamaan nilai LQ dirumuskan Leigh \& Blakely (1994) yang diadopsi oleh Rustiadi et al. (2018) sebagai berikut :

Keterangan :

$$
L Q=\frac{X i j / X .}{X . j / X . .}
$$

Xij : Variabel hasil komoditas sub sektor di Kab. Bombana

Xi. : Jumlah variabel sektor di Kab. Bombana

X.j : Variabel komoditas sektor di Prov. Sulawesi Tenggara (Sultra)

X.. : Jumlah variabel sektor di Prov. Sultra

Berdasarkan rumus persamaan di atas, interpretasi nilai LQ yang diperoleh sebagai berikut (Rustiadi, 2018) :

1) LQ > peranan sektor tersebut lebih besar di Bombana daripada prov. Sultra

2) $\mathrm{LQ}<$ peranan sektor tersebut di Kab. Bombana lebih kecil daripada Prov. Sultra

3) $\mathrm{LQ}=$ Peranan sektor tersebut sama besar di Kab. Bombana dan Prov. Sultra

\section{HASIL DAN PEMBAHASAN}

\section{Kemajuan Desa di Kabupaten Bombana}

Kabupaten Bombana terbagi menjadi 22 kecamatan dengan 123 desa. Kecamatan Poleang Barat memiliki jumlah desa terbanyak dengan 12 desa dan Kecamatan Rumbia terkecil dengan jumlah 2 desa. Penentuan IDM telah ditetapkan di Kab. Bombana sebanyak 121 desa. Terdapat 2 desa yang belum dilakukan penilaian karena baru dibentuk dari hasil pemekaran. Kedua desa tersebut adalah Desa Talabente dari pemekaran Kelurahan Lameroro di Kecamatan Rumbia dan Desa Gambere dari pemekaran Desa Rakadua Kecamapatan Poleang. Tahapan kemajuan desa di Kab. Bombana disajikan pada Tabel 2.

\begin{tabular}{|c|c|c|c|c|c|c|}
\hline \multirow[b]{2}{*}{ No } & \multirow[b]{2}{*}{ Tahapan Desa } & \multirow[b]{2}{*}{ Nilai IDM } & \multicolumn{4}{|c|}{ Tahun } \\
\hline & & & $2015-2018$ & $\begin{array}{c}\text { Persentas } \\
\mathrm{e}\end{array}$ & 2019 & Persentase \\
\hline 1 & Sangat tertinggal & $\leq 0.4907$ & 20 & 16.53 & 9 & 7.44 \\
\hline 2 & Tertinggal & $0.4908-0.5989$ & 94 & 77.69 & 86 & 71.07 \\
\hline 3 & Berkembang & $0.5990-0.7072$ & 7 & 5.78 & 25 & 20.66 \\
\hline 4 & Maju & $0.7073-0.8155$ & 0 & 0 & 1 & 0.83 \\
\hline 5 & Mandiri & $\geq 0.8156$ & 0 & 0 & 0 & 0 \\
\hline & Jumlah & & 121 & 100 & 121 & 100 \\
\hline
\end{tabular}

Tabel 2. Status tahapan desa berdasarkan IDM di Kabupaten Bombana 
Sumber : Kemendesa PDTT, 2016 dan 2019, diolah.

Berdasarkan Tabel 2, Kabupaten Bombana memiliki desa yang mengalami perkembangan ke desa maju. Desa Waemputang, Kecamatan Poleang Selatan dengan nilai IDM 0,7335. Desa ini mengalami peningkatan pada dimensi sosial dan ekonomi. Hal ini relevan dengan penelitian Budiarto et al. (2017) bahwa tipologi perkembangan desa yang maju cenderung memiliki pusat kegiatan ekonomi yang memiliki dampak positif bagi perekonomian masyarakat desa. Partsisipasi masyarakat desa cukup tinggi untuk mengelola potensi lokal sumber daya yang ada di desanya. Dilain sisi, status desa tertinggal dan sangat tertinggal masih banyak sebesar $78,51 \%$. Pada umumnya nilai pada masing-masing dimensi sosial, ekonomi dan lingkungannya berkategori rendah. Indikator pada ketiga dimensi ini pernah disampaikan oleh Soleh (2017), bahwa permasalahan yang dihadapi di desa adalah rendahnya taraf hifup dan kesejahteraan, fasilitas pelayanan masyarakat belum memadai, ketidakmampuan masyarakat dalam usaha ekonomi untuk skses modal dan pemasaran produksi masyarakat desa, tingkat pendidikan dan produktivitas masyaarakat rendah, manajemen pemerintahan desa yang belum optimal, serta sulitnya akses desa tertinggak ke pusat kegiatan ekonomi.

Pendekatan untuk mengatasi pedesaan tertinggal yaitu dengan 3 (tiga) cara, pertama menurunkan angka kemiskinan melalui penguatan tumbuhnya usaha ekonomi masyarakat desa, kedua menurunkan tingkat kebodohan melalui peningkatan kapasitas masyarakat desa dan ketiga dengan pengadaan atau perbaikan sarana prasarana infrastruktur seperti jalan, listrik, air bersih dan lembaga pendidikan (Syahnaz \& Suarman, 2013). Hal ini sesuai dengan (Hakim, 2019), mengemukakan 7 (tujuh) strategi untuk mengentaskan daerah tertinggal adalah desain kawasan perdesaan yang diusulkan oleh masyarakat, perbaikan sarana dan prasarana antar desa, pengembangan kapasitas SDM, pembinaan masyarakat desa, kerjasama dan bantuan anggaran dari pemerintah, kemitraan dengan swasta bagi bisnis ekonomi masyarakat, pemugaran kembali fungsi kelembagaan masyarakat, pengembangan kawasan berdasar komoditas unggulan.

\section{Penilaian Indikator-Indikator Desa Membangun}

Nilai IDM memberikan gambaran untuk pemangku kepentingan untuk mengamati tahapan perkembangan desa melalui aspek sosial, ekonomi dan lingkungan. Nilai indikator-indikator IDM telah diidentifikasi melalui input data-data desa dari aparatur atau pendamping desa. Indikator yang diindikasikan mempunyai nilai rendah dapat dilakukan intervensi program sesuai yang dibutuhkan (Kementerian Desa PDTT, 2016). Profil nilai-nilai indikator IDM Kabupaten Bombana disajikan pada Gambar 1 berikut.

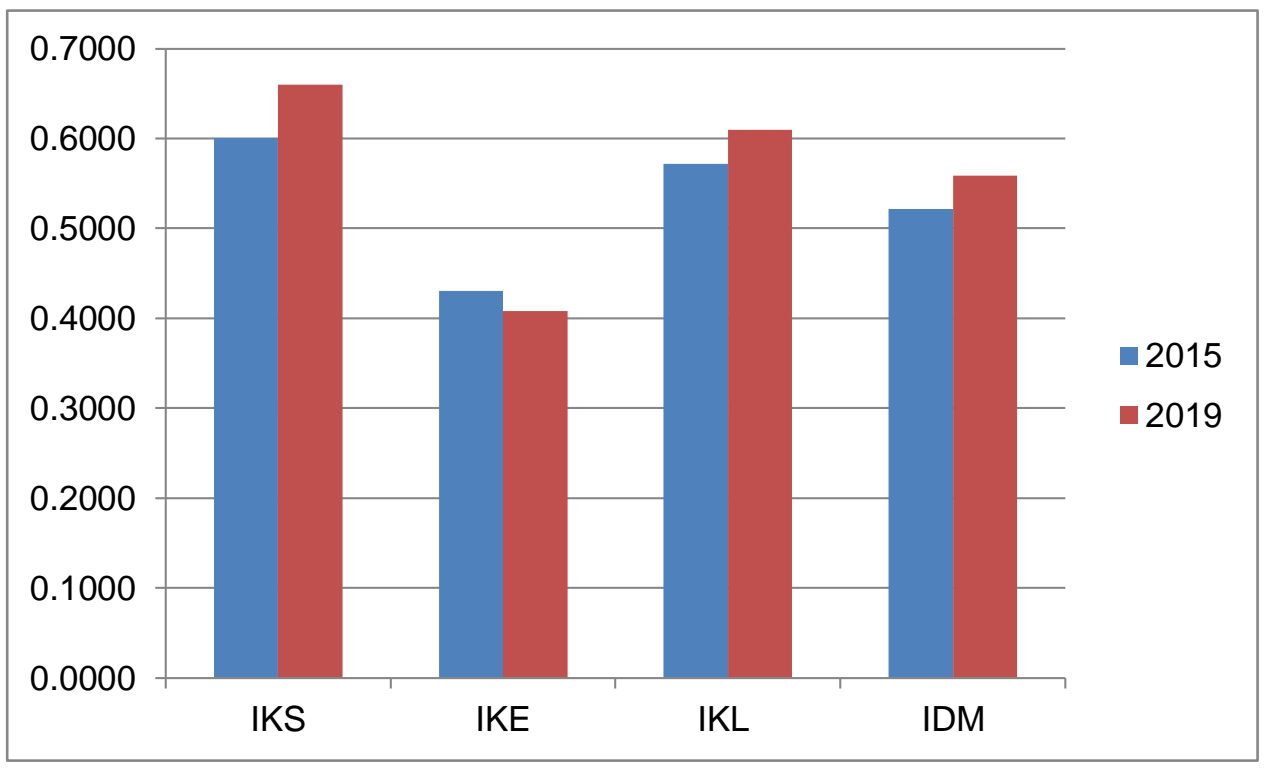

Gambar 1. Rata-rata Indikator IDM 2015-2018 dan 2019 Kabupaten Bombana (Sumber : Kemendesa PDTT, 2019 diolah)

Berdasarkan Gambar 1, nilai Indikator Ketahanan Ekonomi merupakan indikator terendah dari nilai lainnya dan menurun dari tahun 2015 ke tahun 2019. Nilai IKE ini menjadi pembeda yang utama dalam tahapan status kemajuan suatu desa (Muhtarom et al., 2018). Desa Waemputang 
memiliki nilai IKE tertinggi $(0,767)$ dari lainnya sebagai status desa maju. Sedangkan nilai IKE terendah merupakan desa sangat tertinggal dibawah nilai 0,250 . Hal inilah yang menjadi fokus pemerintah untuk melakukan penguatan agar masyarakat desa mampu menumbuhkan usaha ekonomi lokal di desanya. Peran Badan Usaha Milik Desa (BUM Desa) sangat diperlukan untuk meningkatkan kegiatan ekonomi di desa. Sesuai potensi wilayahnya, usaha sarana prasarana, jasa dan hasil produk pertanian serta ekonomi kreatif memiliki potensi yang baik untuk dikembangkan.

Kemajuan suatu desa secara kuantitas berbanding lurus dengan keberadaan unit usaha ekonomi BUM Desa namun secara kualitas maka peranan BUM Desa belum tentu memberikan keuntungan ekonomi bagi masyarakat desa (Sunaryono et al., 2019) BUM Desa dibentuk untuk memiliki usaha ekonomi dan mempunyai nilai sosial dengan melibatkan masyarakat desa sebagai pelaku kegiatan ekonomi dengan memanfaatkan SDA yang ada. Eksistensi BUM Desa memberikan pengaruh positif di bidang ekonomi dan sosial. Keberadaan BUM Desa juga turut menyumbang pendapatan asli desa namun tidak berpengaruh langsung terhadap pendapatan masyarakat (Anggraeni, 2016; Sembiring, 2017). Pemilihan unit-unit usaha pada BUM Desa disesuaikan dengan potensi unggulan yang ada di desa dan atau atau mendukung proses produksi hasil masyarakat sehingga harapannya dapat meningkatkan kesejahteraannya.

\section{Produk Unggulan Komparatif Kabupaten Bombana}

Analisis LQ adalah teknik yang umum digunakan untuk menentukan sektor basis atau unggulan pada suatu wilayah. Hasil LQ merupakan komparasi suatu sektor pada suatu daerah terhadap besarnya peranan sektor yang sama pada daerah yang dijadikan objek penelitian. . Nilai LQ sub sektor tanaman pangan disajikan pada Tabel 3 dan LQ sub sektor peternakan disajikan pada Tabel 4.

Tabel 3. Hasil analisis LQ sub sektor tanaman pangan di Kabupaten Bombana

\begin{tabular}{|c|c|c|c|}
\hline \multirow{2}{*}{ Tanaman Pangan } & \multicolumn{2}{|c|}{ Tahun } & \multirow{2}{*}{ Keterangan } \\
\hline & 2015 & 2018 & \\
\hline Padi & 1.26 & 1.81 & Unggulan Progresif \\
\hline Jagung & 1.01 & 0.17 & Non Unggulan \\
\hline Kedelai & 0.21 & 0.07 & Non Unggulan \\
\hline Kacang Tanah & 0.28 & 0.13 & Non Unggulan \\
\hline Ubi Kayu & 0.17 & 0.08 & Non Unggulan \\
\hline Ubi Jalar & 0.52 & 0.15 & Non Unggulan \\
\hline
\end{tabular}

Sumber : BPS Kab Bombana dan BPS Prov Sultra. Data 2016 dan 2017 tidak tersedia.

Tabel 4. Hasil analisis LQ sub sektor peternakan di Kabupaten Bombana

\begin{tabular}{lcccc}
\hline \multirow{2}{*}{ Jenis Ternak } & \multicolumn{3}{c}{ Tahun } & \multirow{2}{*}{ Keterangan } \\
\cline { 2 - 4 } & 2016 & 2017 & 2018 & Unggulan Progresif \\
Sapi & $\mathbf{1 . 3 2}$ & $\mathbf{1 . 3 5}$ & $\mathbf{1 . 5 5}$ & Unggulan Progresif \\
Kerbau & $\mathbf{2 . 0 3}$ & $\mathbf{2 . 2 4}$ & $\mathbf{4 . 6 9}$ & Unggulan \\
Kuda & $\mathbf{1 . 8 0}$ & $\mathbf{1 . 8 6}$ & $\mathbf{1 . 7 2}$ & Non Unggulan \\
Kambing & 0.64 & 0.60 & 0.49 & Non Unggulan \\
Babi & 0.15 & 0.14 & 0.13 & Unggulan Progresif \\
Ayam Kampung & $\mathbf{1 . 3 2}$ & $\mathbf{1 . 4 7}$ & $\mathbf{1 . 4 9}$ & Non Unggulan \\
Ayam Petelur & $\mathbf{2 . 3 2}$ & 0.41 & 0.44 & Non Unggulan \\
Ayam Pedaging & 0.03 & 0.05 & 0.06 & Non Unggulan \\
ltik/Bebek & 0.41 & 0.25 & 0.23 &
\end{tabular}

Sumber : BPS Kab Bombana dan BPS Prov Sultra (2016-2018).

Berdasarkan Tabel 3 bahwa nilai LQ sub sektor tanaman pangan yang merupakan unggulan adalah tanaman padi. Tanaman jagung sempat memiliki nilai $L Q>1$, namun pada tahun 2018 mengalami penurunan produksi yang signifikan. Produksi padi mengalami kenaikan yang progresif dari tahun 2015 yaitu 82662,4 ton/ha/tahun menjadi 84512 ton/ha/tahun. Kab. Bombana merupakan salah satu penyangga pangan di Prov. Sulawesi Tenggara. Lahan sawah yang paling besar adalah di Kec. Lantari Jaya 3.527 ha, Poleang Timur 2.668 ha, Poleang Utara 1.979 ha dan Rarowatu Utara 1.887 ha. Wilayah di Bombana yang menghasilkan padi terdapat di 18 kecamatan dan yang tidak menghasilkan padi adalah Kec. Kabaena, Kabaena Timur, Kabaena Selatan dan Kepulauan Masaloka Raya yang berada di kepulauan. Hal yang perlu diperhatikan adalah kesejahteraan petani dalam kaitnnya dengan tingkat harga padi atau beras. (Musrifin et al., (2019) bahwa terdapat 
hubungan yang signifikan antara tingkat harga dan kesejahteraan petani. Hal ini bisa menjadi penghambat bila posisi tawar harga beras di petani masih sangat rendah. Peran BUM Desa sangat diharapkan untuk menstabilkan harga posisi tawar harga beras di petani.

Sapriadi \& Hasbiullah (2015) bahwa produk unggulan suatu daerah lebih baik kuantitasnya dibanding produk lainnya pada sektor yang sama atau disebut keunggulan komparatif. Sedangkan produk non unggulan adalah yang potensinya kurang tetapi bisa menjadi pendukung untuk produk unggulan suatu daerah. Faktor-faktor yang mempengaruhi keunggulan komparatif adalah potensi SDA, pemnafaatan teknologi, aksesibilitas, pemasaran, pusat produksi, karakteristik masyarakat, tenaga kerja dan dukungan pemerintah.

Tabel 4 menunjukkan bahwa ternak sapi dan kerbau merupakan jenis ternak unggulan di Kab Bombana. Nilai $L Q>1,0$ yang berarti bahwa populasi ternak tersebut mengalami peningkatan progresif dan mampu memenuhi kebutuhan daging di kabupaten lainnya di Provinsi Sulawesi Tenggara. Hal ini berbeda hasil perhitungan LQ yang dilakukan oleh (Abidin, 2018) bahwa nilai LQ yang menunjukkan komoditas unggulan pada ternak ruminansia besar pada tahun 2016 hanya pada ternak sapi. Komoditas unggulan mengalami pergeseran atau perkembangan di Kabupaten Bombana seiring bertambahnya waktu. Sebagai tambahan, Gazali et al. (2015) dari tahun 2015 ternak sapi bali memberikan sumbangan terbesar bagi petani di kecamatan Poleang Selatan. Selain itu ternak kambing juga potensial untuk dikembangkan karena populasinya surplus di Kab. Bombana. Ternak unggas yang potensial untuk dikembangkan adalah ayam kampung. Masyarakat pada umumnya lebih menyukai konsumsi daging ayam kampung dibanding dengan ayam pedaging. Namun ayam pedaging menunjukkan pola populasi yang meningkat. Populasi ayam petelur sangat baik pada tahun 2016 namun pada tahun berikutnya, kebutuhan telur di Bombana didatangkan dari daerah lain.

\section{KESIMPULAN DAN SARAN}

Identifikasi pada nilai indikator-indikator IDM di Kabupaten Bombana perlu dilakukan untuk menyusun program kebijakan pembangunan desa. Strategi kebijakan difokuskan pada penguatan untuk indikator yang bernilai rendah. Program yang dibentuk disesuaikan dengan usulan dan kebutuhan masyarakat desa. Prioritas pada desa tertinggal bahwa kebijakan yang diambil diharapkan memiliki dampak sosial dan ekonomi melalui peningkatan unit-unit usaha lembaga ekonomi yang ada di desa seperti BUM Desa dan meminimalisasi kerusakan lingkungan. Pengembangan unit usaha ini memanfaatkan potensi unggulan yang ada di Kabupaten Bombana seperti tanaman padi, ternak sapi, kerbau, kambing dan ayam kampung. BUM Desa tidak hanya memperhatikan di on farm saja, tetapi juga memberikan pelayanan pada bantuan proses produksi dan diversifikasi hasil-hasil subsektor pertanian. Keunggulan kompetitif produk Kabupaten Bombana juga perlu dikaji untuk mengetahui daya saing dengan komoditi lainnya dari berbagai daerah baik secara kuantitas maupun kualitas produk.

\section{REFERENSI}

Abidin, Z. (2015). Aplikasi Analisis Shift Share pada Transformasi Sektor Pertanian dalam Perekonomian Wilayah di Sulawesi Tenggara. Informatika Pertanian, 24(2), 165-178. https://doi.org/10.21082/ip.v24n2.2015.p165-178

Abidin, Z. (2018). Identifikasi Komoditas Unggulan Wilayah Dalam Perspektif Pertanian Berkelanjutan di Sulawesi Tenggara. Jurnal Mega Aktiva, 7(2), 39-47. https://doi.org/10.32833/majem.v7i2.71

Affandi, I. M. (2019). Laporan Utama: Dana Desa untuk Infrastruktur Penunjang Aktivitas Ekonomi dan Peningkatan Kualitas Hidup Masyarakat Desa. In Media Komunikasi dan Informasi Desentralisasi Fiskal: Vol. XXII (pp. 19-24). Ditjen Perimbangan Keuangan, Kementerian Keuangan Republik Indonesia.

Anggraeni, M. (2016). Peranan Badan Usaha Milik Desa (Bumdes) Pada Kesejahteraan Masyarakat Pedesaan Studi Pada Bumdes Di Gunung Kidul, Yogyakarta. Modus, 28(2), 155-167. https://doi.org/10.24002/modus.v28i2.848

BPS Kabupaten Bombana. (2019). Statistik Daerah Kabupaten Bombana 2019. Badan Pusat Statistik Kabupaten Bombana. Bombana.

Budiarto, T., Rustiadi, E., \& Dharmawan, A. H. (2017). Perkembangan dan kemandirian desa di Kabupaten Bogor, Provinsi Jawa Barat. Tata Loka, 19(3), 230-241. https://doi.org/10.14710/tataloka.19.3.230-241

Gazali, Nafiu, L.O., \& Sani, L.O.A. (2015). Kontribusi Usaha Ternak Sapi Bali Terhadap Total Pendapatan Kabupaten Bombana. Jitro, 2(3), 68-87. https://doi.org/10.33772/jitro.v2i3 
Hakim, A. L. (2019). Strategi Pengembangan Kawasan Perdesaan: Studi di Kabupaten Pandeglang. Sawala : Jurnal Administrasi Negara, 7(1), 12-28. https://doi.org/10.30656/sawala.v7i1.906

Jufriyanto, M. (2019). Pengembangan Produk Unggulan Sebagai Potensi Peningkatan Ekonomi Masyarakat Desa di Kecamatan Modung Bangkalan. Jurnal Ilmiah Pangabdhi, 5(1), 28-32. https://doi.org/10.21107/pgd.v5i1.5162 Artikel

Jumiadin \& Sunarwan, A. (2018). Kajian Aspek Lingkungan Hidup Pada Pengukuran Pembangunan Desa di Kabupaten Wakatobi. Ecogreen, 4(2), 73-83.

Muhtarom, Kusuma, N., \& Purwanti, E. (2018). Analisis Indeks Desa Membangun Untuk Mengetahui Pola Perkembangan Pembangunan Desa di Kecamatan Gadingrejo Kabupaten Pringsewu. Inovasi Pembangunan: Jurnal Kelitbangan, 6(02), 179-190. https://doi.org/10.35450/jip.v6i02.96

Musrifin, A., Buana, T., \& Mardin. (2019). Faktor-Faktor Penghambat Kesejahteraan Petani Padi Sawah di Desa Sangia Makmur Kecamatan Kabaena Utara Kabupaten Bombana. Jurnal Ilmiah Membangun Desa Dan Pertanian, 4(1), 7-11. https://doi.org/10.33772/jimdp.v4i1.6409

Kementerian Desa PDTT. (2016). Peraturan Menteri Desa, Pembangunan Daerah Tertinggal, Dan Transmigrasi Republik Indonesia Nomor 2 Tahun 2016 Tentang Indeks Desa Membangun. Kementerian Desa PDTT.

Kementerian Desa PDTT. (2019). Keputusan Menteri Desa, Pembangunan Daerah Tertinggal, Dan Transmigrasi Nomor 79 Tahun 2019 Tentang Penetapan Kabupaten Daerah Tertinggal Yang Terentaskan Tahun 2015-2019. Kementerian Desa PDTT.

Pemerintah Republik Indonesia. (2019). Undang-Undang Republik Indonesia Nomor 20 Tahun 2019 tentang Anggaran Pendapatan dan Belanja Negara Tahun Anggaran 2020. Kementerian Sekretariat Negara RI.

Rustiadi, E., Saefulhakim, S., \& Panuju, D. R. (2018). Perencanaan dan Pengembangan Wilayah (Edisi Kedu; A. E. Pravitasari, Ed.). Jakarta: Crestpent Press dan Yayasan Pustaka Obor Indonesia. Jakarta.

Sapriadi \& Hasbiullah. (2015). Analisis Penentuan Sektor Unggulan Perekonomian Kabupaten Bulukumba. Jurnal lqtisaduna, 1(1), 53-71. https://doi.org/10.24252/iqtisaduna.v1i1.1155

Sembiring, S. (2017). Keberadaan Badan Usaha Milik Desa Dalam Meningkatkan Pendapatan Asli Desa. Kertha Patrika, 39(1), 16-32. https://doi.org/10.24843/KP.2017.v39.i01.p02

Setyobakti, M. H. (2017). Identifikasi Masalah Dan Potensi Desa Berbasis Indek Desa Membangun (IDM) Di Desa Gondowangi Kecamatan Wagir Kabupaten Malang. Wiga: Jurnal Penelitian Ilmu Ekonomi, 7(1), 1-14. https://doi.org/10.30741/wiga.v7i1.331

Setyowati, E. (2019). Tata Kelola Pemerintahan Desa Pada Perbedaan Indeks Desa Membangun (IDM): Studi Tiga Desa Di Kabupaten Malang. Jispo, 9(2), 170-188. https://doi.org/10.15575/jispo.v9i2.5324

Soleh, A. (2017). Strategi Pengembangan Potensi Desa. Jurnal Sungkai, 5(1), 32-52. https://doi.org/10.30606/js.v5il.1181

Sunaryono, Salahuddin, M., Dilla, Z. P. (2019). Peranan Badan Usaha Milik Desa Pada Kesejahteraan Masyarakat Pedesaan (Studi Kasus Pada BUMDES Di Kabupaten Mempawah, Kalimantan Barat). Jurnal Ekonomi STIEP, 4(2), 1-8.

Suroso. (2019). Eksistensi Pembangunan Masyarakat dan Desa di Kawasan Perkotaan Kabupaten Pati. Jurnal Litbang Media Informasi Penelitian, Pengembangan Dab IPTEK, XV(2). https://doi.org/10.33658/jl.v15i2.140

Syahza, A., \& Suarman. (2013). Upaya Percepatan Pembangunan Ekonomi Pedesaan. Jurnal Ekonomi Pembangunan, 14(1), 126-139. https://doi.org/10.23917/jep.v14i1.166

Yunisa, I., Nastis, M., \& Rahim, M. (2019). Analisis Penerapan Kebijakan Program Gembira Desa Terhadap Rencana Pembangunan Desa di Kecamatan Kabaena Selatan Kabupaten Bombana (Studi Kasus: Desa Batuawu, Langkema, Ponunu dan Pongkalaero). Jurnal Perencanaan Wilayah, 4(1), 1-12. https://doi.org/10.33772/jpw.v4i1.7463 